\title{
CLASSIFICATION OF A POSITIONING STRATEGY OF NIGHT MARKETS AS SHOPPING TOURIST DESTINATION
}

\author{
Nealnara Wongkerd ${ }^{1}$
}

\begin{abstract}
Shopping at night markets is one of the most enjoyable ways for tourists who can get opportunity to getting up close local life in Thailand's capital. While tourists continually seek more diverse and rich experiences through a new adventures and new locations, night markets are spread out in most areas of the city and offer an incredibly diverse range of foods, goods and products, and entertainment. This article attempts to outline the theoretical backgrounds of night markets by introducing the views and results of the most relevant researchers in this field. First, the international literature is reviewed, then the most comprehensive case studies in night markets characteristics are introduced, finally the results of night markets case studies are outlined with a special emphasis in Bangkok. The study areas covered more than twenty night markets in Bangkok. Night markets' characteristics and their position strategy are clustered to discern common pattern that are used in classifying night market characteristics. The contribution of this study will offer a comprehensive framework that can be used as a basis for more discussion and future research.
\end{abstract}

Key words: shopping tourism, night markets, positioning strategy, Thailand

\section{INTRODUCTION}

Tourists continually seek more independently travel characteristics, diverse activities, and rich experiences through a new adventures and new locations. Tourist destinations complete in many areas of the city and offer diverse range of goods and products, snacks and entertainment; after dark shopping opportunities mean incredible bargains in the evening to nighttime. Night markets, tourist walking streets, and weekend markets in Bangkok are the easiest and major places of getting up close and personal between local vendors and tourists in Thailand's capital. They are huge open-air bazaar selling array of collectable items and local products - some crafted by skilled local artists, some pumped out by factory items, others sourced from secondhand stalls in home decorations, clothes, souvenirs, bars and live musics. Therefore, Bangkok night markets have become popular among young and foreign tourists.

With the demand for shopping among tourists can lead improving local economies, the development of shopping tourism is a phenomenon that is attracting increased attention from government sectors, academics and

\footnotetext{
${ }^{1}$ Full-time Lecturer, Faculty of Business Administration in Tourism, Ramkhamheang
} University., nealnara@hotmail.com 
business entrepreneurs worldwide. Therefore, shopping tourism has been a fertile subject of exploration for tourism researchers, not just in an economic sense but also in terms of tourists' motives and social encounters. Previous research in tourism shopping has explored various aspects of shopping including: the role of shopping in destination choice (Moscardo, 2004) the determinants of tourist shopping experience satisfaction (Reisinger \& Turner, 2002), motives for shopping activity engagement (Timothy, 2005), product preferences and expenditure patterns (Mok \& Lam, 1997) and a typology of shoppers (Paige \& Littrell, 2003).

Having been confronted with new challenges, tourism night markets were forced to accept new ways of new business models, more local and global competitors, substantial channel distribution in order to drive more tourists visit and shop in the market. Since increased competition always implies the need for a more intensive use of marketing (Hemsley-Brown \& Oplatka, 2006), these tourism night markets need to develop and apply different marketing strategies (Kotler, 2012), primarily for the purposes of gaining a competitive advantage and increasing their market share in the local and global markets.

One of the most significant marketing strategies that enable the achievement of these goals is the positioning strategy. It is the subject matter of this study. After a brief comment on the specifics of the positioning strategy in the context of tourism night markets, this paper provides an analysis of the bases on which the positioning strategies of the tourism night markets in the Bangkok, Thailand are established. This article attempts to outline the theoretical backgrounds of night markets by introducing the views and results of the most relevant researchers in this field. The study areas covered twenty night markets in Bangkok. Night markets' characteristics and their position strategy are clustered to discern common pattern that are used in classifying night market characteristics. The final part of the paper contains concluding remarks and guidelines for future research.

\section{REVIEW OF LITERATURE}

\section{Previous studies on Shopping Tourism}

Shopping tourism is another important form of tourism. Most researchers agree that shopping is one of the critical driving forces for tourists to visit destinations. Hsieh and Chang (2006) perceived shopping as the core leisure activity during a trip. Heung and Cheng (2000) also believed that travel is incomplete without shopping. Turner and Reisinger (2001) reinforced such an opinion by arguing that tourists tend to allocate a higher budget for 
shopping than for other expenses, such as dining, accommodation, or sightseeing. Furthermore, Tosun, Temizkan, Timothy, and Fyall (2007) suggested that a well-managed shopping experience forms a favorable tourist destination image. In addition, studies have attempted to develop a scale that measures tourist shopping satisfaction. Wong and Wan (2013) identified the sub-dimensions of tourist shopping satisfaction and evaluated the relationship among destination facilities (i.e., safety, transportation, location, and cleanliness), tourist shopping satisfaction (i.e., service product and environment satisfaction, merchandise value satisfaction, and service differentiation satisfaction), and overall shopping experience. Their findings revealed that satisfied tourists tend to stay long and allocate high budgets during their trips. Scholars have generally agreed that shopping is a key factor that attracts tourists and have mainly highlighted the positive aspects of tourist shopping, namely, antecedents and behavioral intentions.

\section{Tourism Night Markets Background in Thailand}

Table 1: Night Markets in Bangkok Characteristics in this study

\begin{tabular}{|l|l|}
\hline & Characteristics \\
\hline $\begin{array}{l}\text { 1. Rod Fai (Train } \\
\text { location }\end{array}$ & $\begin{array}{l}\text { Rod Fai, or commonly referred to as the 'Train } \\
\text { Market', got its name from the original Rod Fai } \\
\text { night market located next to the train tracks on the } \\
\text { outskirts of Bangkok. As in all markets in Bangkok, } \\
\text { at the new Rot Fai Market Ratchada bargaining is } \\
\text { expected as there is no set price for anything. This } \\
\text { market is so popular with Thai people prices. }\end{array}$ \\
\hline $\begin{array}{l}\text { 2. JJ Green (Vintage } \\
\text { Market) }\end{array}$ & $\begin{array}{l}\text { JJ Green is set up one part flea market and one part } \\
\text { standard, tented night market. In the flea market } \\
\text { area tourists will find vintage items sprawled across } \\
\text { organized rows of sheets on the ground. Items for } \\
\text { sale range from license plates, to watches, to } \\
\text { useless old car parts. }\end{array}$ \\
\hline $\begin{array}{l}\text { 3. Asiatique The } \\
\text { Riverfront }\end{array}$ & $\begin{array}{l}\text { Located along the Chao Praya River (famous river), } \\
\text { Asiatique is a night market with a river view that } \\
\text { attract both tourists and locals to come here to catch } \\
\text { the sunset. }\end{array}$ \\
\hline
\end{tabular}




\begin{tabular}{|c|c|}
\hline & Characteristics \\
\hline $\begin{array}{l}\text { 4. Saphan Phut Night } \\
\text { Market (Memorial Bridge } \\
\text { Market) }\end{array}$ & $\begin{array}{l}\text { Lots of the stalls here sell shoes and clothing geared } \\
\text { towards a youthful generation. Tourists can even find a } \\
\text { few tattoo and piercing stalls if you are feeling a little } \\
\text { rebellious. }\end{array}$ \\
\hline 5. Indy Night Market & $\begin{array}{l}\text { Despite being smaller than other night markets, } \\
\text { there is reason to visit this place for the many } \\
\text { handmade and unique products that are available for } \\
\text { sale here. Most items also cost less than 100THB ( } \\
=3 \text { US dollar). }\end{array}$ \\
\hline $\begin{array}{l}\text { 6. Talad Nud Liab Duan } \\
\text { Ramintra }\end{array}$ & $\begin{array}{l}\text { There are many stalls that sell clothing, shoes, and } \\
\text { accessories. There is even shopping that can be } \\
\text { done on such as pet shops, nail manicures, and } \\
\text { barbers shops. }\end{array}$ \\
\hline 7. ChangChui & $\begin{array}{l}\text { This market designed an art into its unique setting. } \\
\text { Much of the design here stems from the philosophy } \\
\text { to "Reuse". } \\
\text { It is also interesting to note that most of this market } \\
\text { is run by Thai artists from across the country. }\end{array}$ \\
\hline 8.On Nut Night Market & $\begin{array}{l}\text { The shopping at On Nut is pretty small compared to } \\
\text { the other night markets, nothing really out of the } \\
\text { ordinary or unusual. The real pull here is the } \\
\text { convenient city location, comfortable laid-back vibe } \\
\text { and overall chilled out, welcoming space to relax } \\
\text { and hangout for an evening. }\end{array}$ \\
\hline 9. Artbox Night Market & $\begin{array}{l}\text { It is important to note that unlike other markets, } \\
\text { Artbox does not always open at the same location. } \\
\text { The location shifts around Thailand and even } \\
\text { internationally. The giant metal shipping containers } \\
\text { serve the purpose for this mobility. Tourists can } \\
\text { find location updated through their Facebook page. }\end{array}$ \\
\hline $\begin{array}{l}\text { 10. Victory Monument } \\
\text { Night Market }\end{array}$ & $\begin{array}{l}\text { This night market is one of the best places to go to } \\
\text { get an awesome deals of products. Discerning } \\
\text { shoppers will know that this place offers better } \\
\text { bargains on fashion, accessories, shoes, mobile } \\
\text { phone accessories and many more compared to } \\
\text { shopping malls. }\end{array}$ \\
\hline
\end{tabular}




\begin{tabular}{|l|l|}
\hline & Characteristics \\
\hline $\begin{array}{l}\text { 11. Talad Neon Night } \\
\text { Market }\end{array}$ & $\begin{array}{l}\text { The market is located near Platinum Fashion Mall. } \\
\text { This night market was opened to fanfare at the end } \\
\text { of 2016 and then was intended to be continued for } \\
\text { trading, like other night markets, Talad Neon's } \\
\text { collection of fashion and souvenir stalls, food } \\
\text { vendors, and outdoor bars. }\end{array}$ \\
\hline 12. Hua Mum Night & $\begin{array}{l}\text { Hua Mum night market is apparently a hidden place } \\
\text { that is not known to many tourists. Shoppers will } \\
\text { find everything they want, such as handcrafted } \\
\text { items, fashionable clothes and delicious food. }\end{array}$ \\
\hline 13. Khao San Road & $\begin{array}{l}\text { Khao San Road is famous for being backpacker area } \\
\text { as there are many budget hotels and bars located } \\
\text { there. Khao San Road has a lively atmosphere as } \\
\text { people walking along the streets for some Thai } \\
\text { massages, shopping, parties, and some food from } \\
\text { the many restaurants and bars. }\end{array}$ \\
\hline $\begin{array}{l}\text { 14.Suan Lum Night } \\
\text { Bazaar Ratchada }\end{array}$ & $\begin{array}{l}\text { With 1,800 stalls, shops, restaurants and plenty of } \\
\text { entertainment options, it is looking to recreate the } \\
\text { experience of the original Sun Lum Night Bazaar, which } \\
\text { was a mainstay on tourists' itineraries until it closed } \\
\text { several years ago. The shops and stalls are split between } \\
\text { an indoor market area and an open air shopping street. } \\
\text { The type of items for sale are fairly typical of night } \\
\text { markets in Bangkok, including printed tees, shoes, } \\
\text { fashion jewellery, artwork, wood carvings, and a host of } \\
\text { souvenirs. }\end{array}$ \\
\hline $\begin{array}{l}\text { This place is over 50 international restaurants } \\
\text { including Thai, Japanese, Italian and Mexican for } \\
\text { you to choose from, along with the stylish interior } \\
\text { and decoration either on the style of the shops or the } \\
\text { food, boasting their uniqueness and 'out of the } \\
\text { ordinary' characters. }\end{array}$ \\
$\begin{array}{l}\text { Located on the bank of the Chao Phraya river, Tha } \\
\text { Maharaj is surrounded by rich cultural heritage and } \\
\text { tourist attraction of Thai arts, museums, The Grand } \\
\text { Palace, Wat Pho, Wat Arun The Temple of Dawn, } \\
\text { Thammasat University, Silapakorn Fine Arts }\end{array}$ \\
\hline Thanaj
\end{tabular}




\begin{tabular}{|c|c|}
\hline & Characteristics \\
\hline & University, and Siriraj Hospital. \\
\hline 17. OWL night market & $\begin{array}{l}\text { On Friday and Saturday, the market opens all night } \\
\text { until } 10 \text { am the next day. All vendors are fully set } \\
\text { up around } 7 \mathrm{pm} \text { with colourful and brightly lit stalls. } \\
\text { Shoppers can find everything from clothes to the } \\
\text { most outlandish objects. Even the smallest budget } \\
\text { can go very far. Everything here is cheaper than } \\
\text { Bangkok's city markets. This market is ideal for the } \\
\text { adventurous visitor looking for an experience } \\
\text { among the locals. }\end{array}$ \\
\hline $\begin{array}{l}\text { 18. Ramkhamhaeng } \\
\text { University Night Market }\end{array}$ & $\begin{array}{l}\text { Ramkhamhaeng University Night Market is a } \\
\text { market primarily for the locals, it's positioned just } \\
\text { opposite Ramkhamhaeng University, everything } \\
\text { sold here is practical and really for the everyday } \\
\text { student - cheap Thai food like meat skewers, sticky } \\
\text { rice in bags, milk tea, and curries, as well as clothes, } \\
\text { accessories, etc. }\end{array}$ \\
\hline 19. RUNWAY3119 & $\begin{array}{l}\text { Runway3119 Night Market is the best flea market } \\
\text { in Bangkok where located near Suvarnabhumi } \\
\text { Airport only } 5 \text { minutes by car. Runway3119 Night } \\
\text { Market is full of Thai famous street foods, fashion, } \\
\text { electronic goods, bar and restaurants suit to all ages } \\
\text { of tourists around the world to visit and chilling } \\
\text { place before arrival or departure Suvarnabhumi } \\
\text { Airport which provide you full of happiness. }\end{array}$ \\
\hline $\begin{array}{l}\text { 20. Bangkok Chinatown } \\
\text { (YAOWARAT NIGHT } \\
\text { MARKET) }\end{array}$ & $\begin{array}{l}\text { Bangkok's Chinatown, Thailand's largest Chinese } \\
\text { community, is commonly known among Thais as } \\
\text { Yaowarat, according to the name of the road where } \\
\text { it is located. The construction of Yaowarat Road } \\
\text { hadn't begun until } 1891 \text { during the reign of King } \\
\text { Rama V. Today, Yaowarat is widely known as the } \\
\text { kingdom's largest center of gold trade and a great }\end{array}$ \\
\hline
\end{tabular}




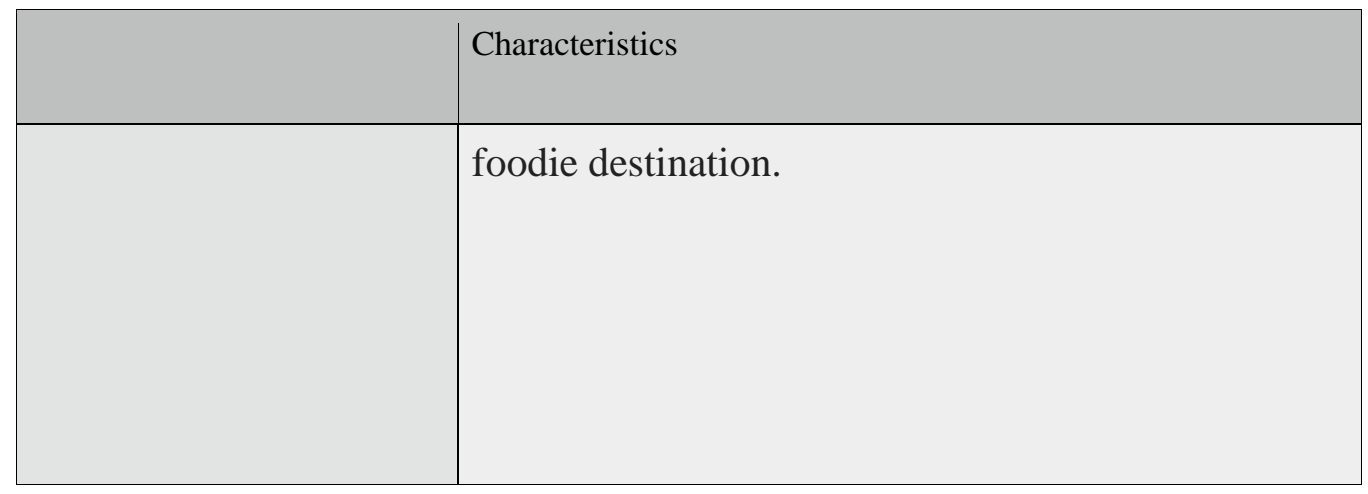

Night Market is, sometime called "Talad Nad" in Thai, especially common in Thailand and other Asia countries. This type of store activity is characterised by the mobile nature of the market/stalls, the linear alignment of stalls along streets and the occupation of private and public land for hawking which, ordinarily, is used for other purposes, such as the setting up of market stalls in a public car park. The night market is one of the most popular shopping options among locals and international tourists, with unique consumption activities, displays, products, and bargain prices which provides a true experience of modern nightlife.

Table 1describes twenty night markets' characteristics. The size of the night markets ranges from a congregation of less than ten stalls to over 200 stalls arranged linearly in one or more rows depending on the shape of the site. They are huge open-air bazaar selling array of collectable items and local products - some crafted by skilled local artists, some pumped out by factory workers, others sourced from second-hand stalls, souvenirs, bars and live musics, local customs; many sell varieties of traditional products, such as casual clothes, fruit, exotic snacks, and novelty items.They usually operate at night and are generally dedicated to more leisurely strolling, shopping, and eating than more businesslike day markets. The peak trading period for the night markets stretches from about $6.30 \mathrm{pm}$ to $10.30 \mathrm{pm}$. While most tourism night market hawkers are into full-time vendors, a great number of them also work in the day in other occupations.

\section{Positioning Strategy of Tourism Night Markets}

Positioning is the act of designing the company's offering and image to occupy a distinctive place in the target market's mind. Positioning is what the customer believes based on his/her experiences and evidence, rather than just the awareness created by advertising or promotion. In other words, 
positioning is "the process of designing an image and value so that customers within the target market understand what the organization or brand stands for in relation to the competition" (Ibrahim \& Gill, 2005). These definitions lead to the conclusion that positioning is primarily focused on the competition and consumers - the goal is for consumers to perceive the organization and its offer as different from and superior to other organizations and their offers.

Instead of emphasizing the same or similar characteristics, it is suggested that night markets should base their positioning and the consequent marketing communication on unique or specific physical elements of their offer, but also on the intangible elements such as reputation (Williams, 2001) or specific added value they offer to customers (Mazzarol \& Hosie, 1996). One study (Lee, S. H., Chang, S.C., You, J.S., \& Lin, C.H. (2008) identified eight main dimensions on which a night market may be based on:

- Local food and specialty (interesting products, alternative choices of commodities, famous local snacks, various food and drink)

- Atmosphere (attractive music, novelty of games and performances, attractive lighting and shop billboards, friendly and courteous vendors, be able to access and feel mirthful atmosphere)

- Public facility (clear sign and notices, parking space, walking path, public facilities)

- Environment (Security, ambience, food sanitary, overall crowded)

- Products (quality of products, fashionable products, local characteristics of products)

- Price (fair and reasonable prices, good value of money)

- Bargain (price negotiation, special discount activity, wide ranges of international food)

- Reputation (well-known reputation, representative localize vendors)

\section{METHODOLOGY}

This study implemented qualitative approach in collecting information. Both primary and secondary data were collected. Field observation was a set of information that collected from 20 night markets. Secondary data were collected in the form of a literature review of existing data and information on both published and unpublished researches. 


\section{FINDINGS}

The results in Table 2 showed night market position classifying in four categories: types of products or services, tourists' trends, competitors, and users' advantages.

\begin{tabular}{|c|c|}
\hline $\begin{array}{l}\text { Night Market in } \\
\text { Bangkok }\end{array}$ & Market Positioning \\
\hline $\begin{array}{l}\text { Categorized by } \\
\text { types of products or } \\
\text { services }\end{array}$ & $\begin{array}{l}\text { - } \text { Convenience goods and food }(6,8,11,12,13,15,17,19,20) \\
\text { - Antiques, collectable and second-handed items }(1,2,7) \\
\text { - Arts and creative handmade }(3,9,14,16) \\
\text { - Cheap and unbeatable price }(4,5,10,18)\end{array}$ \\
\hline $\begin{array}{l}\text { Categorized by } \\
\text { tourists' trends }\end{array}$ & $\begin{array}{l}\text { - The rise in demand of authentic local experience } \\
(1,2,5,6,11,14,19) \\
\text { - } \text { The rise of gastronomy tourism }(8,12,13,15,20) \\
\text { - Emerging new destination will take spotlight }(3,7,9,16,18) \\
\text { - Cheaper is better }(4,10,17)\end{array}$ \\
\hline $\begin{array}{l}\text { Categorized } \\
\text { competitors }\end{array}$ & $\begin{array}{l}\text { - } \text { Mobility markets }(9) \\
\text { - } \text { Outdoor bazzaar }(1,2,4,5,6,8,10,11,12,14,15,17,18,19) \\
\text { - Tourist focus }(3,13,16,20) \\
\text { - Go green }(7)\end{array}$ \\
\hline $\begin{array}{l}\text { Categorized by } \\
\text { users' advantages }\end{array}$ & $\begin{array}{l}\text { - Novelty seeking }(7,20) \\
\text { - } \text { Cultural experience }(1,4,5,6,8,10,11,12,14,17,18) \\
\text { - } \text { Social contact }(2,13,15) \\
\text { - Relaxation }(3,9,16,19)\end{array}$ \\
\hline
\end{tabular}

\section{Table 2: Night Market Positioning in Bangkok}

Source: Provided by author

Twenty night markets from Tables one were classified into each segment. The result of market positioning may help night market entrepreneurs to develop promotion strategy targeted their target markets. For example, many night markets' positioning are "Convenience goods and food" which means night markets that can offer characteristically local products, diverse food and drink, low-price products, and distinctively flavored foods will attract visitors. Moreover, Tourism Authority of Thailand may promote Thai foods and beverages to overseas tourists by using think, sense, and feel experiential marketing method, or may segment visitors by socio-demographics and 
geographic variables. Some benefits may accrue from promotion of factors such as Thai's reputation, special local experience, and public facility, but the primary benefit will arise from strengthening the image of night markets as representative of Thai's attractions.

\section{SUMMARY}

1. Night market vendors. Food outlets should provide authentic Thai food taste as a result tourists have been changed and emerged their lifestyles' trends such as tourists' novelty and authenticity-seeking experiences are on a rise as well as sanitary of food, product differentiation, uniqueness and creativity, good value of money, price-tag or ability to negotiating price and product warranty.

2. Night market organizers. Night market organizers should carefully select qualified vendors, layout management, rules \& regulation management, environmental concern, space quality, sanitary and safety, promotion strategy). The layout of night markets should be planned more sensibly to contribute to visitors' convenience and shopping enjoyment. With restriction to the parking and traffic issues, modern parking garages should be built to accommodate visitors to these night markets. Also, to attract more tourists, a complimentary bus service could be arranged to pick up visitors in between night markets and the major transit stops, such as mass rapid transit BTS stations and bus stations. Most night markets do not consider price competition as the best competition, as a result, the quality, Epromotion, product differentiation, and customer-orientation could be emphasized for positively sustainable development image.

3. Tourism and Government sectors. The suggestions for the relevant tourism and government authorities are provided in several ways. Additional regulatory attention might be given to food sanitation and the eating environment in order to encourage especially other international tourists to shop and eat in night markets. For the importance of maintaining service quality, illegal street vendors (especially selling couterfeit items) should not be allowed to sell in night markets. The police department should make their rounds in these night markets more often on a routine basis to maintain safe atmosphere. 


\section{Limitations of the study}

1. The results of this study is based on researcher observation, therefore it is needed more data collection to generalize future studies such as tourists, shopper, and vendors.

2. This study focused on the study in positioning strategy. This could be suggested to develop different night market perspectives for example, tourists' demand and supply, community engagement, sustainability of night markets.

3. The scope of the study was cover night markets in Bangkok only. Future studies will recommend to cover in different types of markets and provinces for example, tourist walking street, weekend flea market and focus in different areas of visitors such as strengthening the image of night markets, tourists' behaviours and motivation factors.

\section{REFERENCES}

1. Hemsley-Brown, J., \& Oplatka, I. (2006). Universities in a competitive global marketplace: A systematic review of the literature on higher education marketing. International Journal of public sector management, 19(4), 316-338.

2. Hsieh, A. T., \& Chang, J. (2006). Shopping and tourist night markets in Taiwan. Tourism Management, 27(1), 138-145.

3. Heung, V. C., \& Cheng, E. (2000). Assessing tourists' satisfaction with shopping in the Hong Kong special administrative region of China. Journal of Travel Research, 38(4), 396-404.

4. Ibrahim, E. E., \& Gill, J. (2005). A positioning strategy for a tourist destination, based on analysis of customers' perceptions and satisfactions. Marketing Intelligence \& Planning, 23(2), 172-188.

5. Kotler, P. (2012). Kotler on marketing. Simon and Schuster.

6. Lee, S-H., Hou, J-S., Heng, S-T., Hou, L-C. and Lee, C-H. (2005). Night market types and street vendor behavior in Taichung. Taiwan, Journal of Asian Urban Studies, 6(2),11-24.

7. Mok, C., \& Lam, T. (1997). A Model of Tourists'shopping Propensity: A Case of Taiwanese Visitors to Hong Kong. Pacific Tourism Review, 1(2), 137-145.

8. Moscardo, G. (2004). Shopping as a destination attraction: An empirical examination of the role of shopping in tourists' destination choice and experience. Journal of Vacation Marketing, 10(4), 294-307.

9. Paige, R. C., \& Littrell, M. A. (2003). Tourism activities and shopping preferences. Journal of Shopping Center Research, 10(2), 7-25.

10. Reisinger, Y., \& Turner, L. W. (2002). The determination of shopping satisfaction of Japanese tourists visiting Hawaii and the Gold Coast compared. Journal of Travel Research, 41(2), 167-176. 
11. Timothy, D. J. (2005). Shopping tourism, retailing and leisure. Channel View Publications.

12. Tosun, C., Temizkan, S. P., Timothy, D. J., \& Fyall, A. (2007). Tourist shopping experiences and satisfaction. International Journal of Tourism Research, 9(2), 87-102.

13. Turner, L. W., \& Reisinger, Y. (2001). Shopping satisfaction for domestic tourists. Journal of Retailing and consumer services, 8(1), 1527.

14. Williams, P. (2001). Positioning wine tourism destinations: an image analysis. International Journal of Wine Marketing, 13(3), 42-58.

15. Wong, I. A., \& Wan, Y. K. P. (2013). A systematic approach to scale development in tourist shopping satisfaction: Linking destination attributes and shopping experience. Journal of Travel Research, 52(1), 29-41.

16. Bangkok.com (2018). The 6 best Night Markets in Bangkok. Retrieved from http://www.bangkok.com/magazine/best-night-markets.htm, 18 March 2018.

17. Sethlui.com (July, 2018). 11 Best Bangkok Night Markets to Visit For a Taste of Thailand. Retrieved from https://sethlui.com/6-best-bangkoknight-markets-to-visit-for-a-taste-of-thailand/, September 2018.

18. Expique.com (July, 2018). The newest Bangkok Night Market. Retrieved from https://www.expique.com/blog/2018/07/16/newest-bangkok-nightmarkets/, August 2018. 